\title{
INVESTIGATION OF MICROSTRUCTURAL AND HARDNESS CHANGES OF AA7075 ALLOY PROCESSED BY ECAP
}

\author{
Guzide Meltem LULE SENOZ ${ }^{*}$, Dogacan OZTURK ${ }^{1}$
}

${ }^{1}$ Atatürk Unıversity, Department of Metallurgical and Materials Engineering, Erzurum, Turkey

\begin{tabular}{l}
\hline Keywords \\
\hline Severe Plastic Deformation, \\
Equal Channel Angular \\
Pressing (ECAP), \\
Al-Zn-Mg Alloy, \\
Microstructure, \\
Hardness.
\end{tabular}

\begin{abstract}
This study aims to examine the change in microstructural and hardness values AA7075 aluminum alloy, which is frequently preferred in the aviation industry by applying the Equal Channel Angular Pressing (ECAP) method. ECAP method, one of the plastic deformation methods, has been successfully carried out by applying $0.025 \mathrm{~mm} / \mathrm{sec}$ pressing speed and $200^{\circ} \mathrm{C}$ temperature for a different route $(\mathrm{A}, \mathrm{Bc}, \mathrm{C})$ and the different number of passes $(2,4,8)$. The characterization of the aluminum alloy obtained by applying ECAP process was carried out by optical microscope (OM), X-ray diffraction (XRD), and scanning electron microscope (SEM) analysis. Hardness tests have been applied to examine the mechanical properties of the material. The microstructures of the materials obtained as a result of the application were examined. It was observed that precipitation occurred in the AA7075 alloy depending on the applied temperature, pressing, and grain breakage. Moreover, it is seen that the grain size of the materials produced by the ECAP method has been reduced, and consequently the strength of the material increases. As a result of the ECAP process, it was seen that the existing phases were $\alpha-\mathrm{Al}, \eta-\mathrm{MgZn} 2, \mathrm{~S}-\mathrm{Al} 2 \mathrm{CuMg}$, and Al7Cu2Fe. The grain size of $288.4 \mathrm{~nm}$ obtained after 8 repeated passes using the Bc route was the smallest grain size obtained.
\end{abstract}

\section{ECAP UYGULANAN AA7075 ALAŞIMININ MİKRO YAPI VE SERTLİK DEĞİŞİMLERİNİN İNCELENMESİ}

\begin{tabular}{|c|c|}
\hline Anahtar Kelimeler & Öz \\
\hline $\begin{array}{l}\text { Aşırı Plastik Deformasyon, } \\
\text { Eş Kanallı Açısal Presleme, } \\
\text { Al-Zn-Mg Alaşımı, } \\
\text { Mikroyapı, } \\
\text { Sertlik. }\end{array}$ & 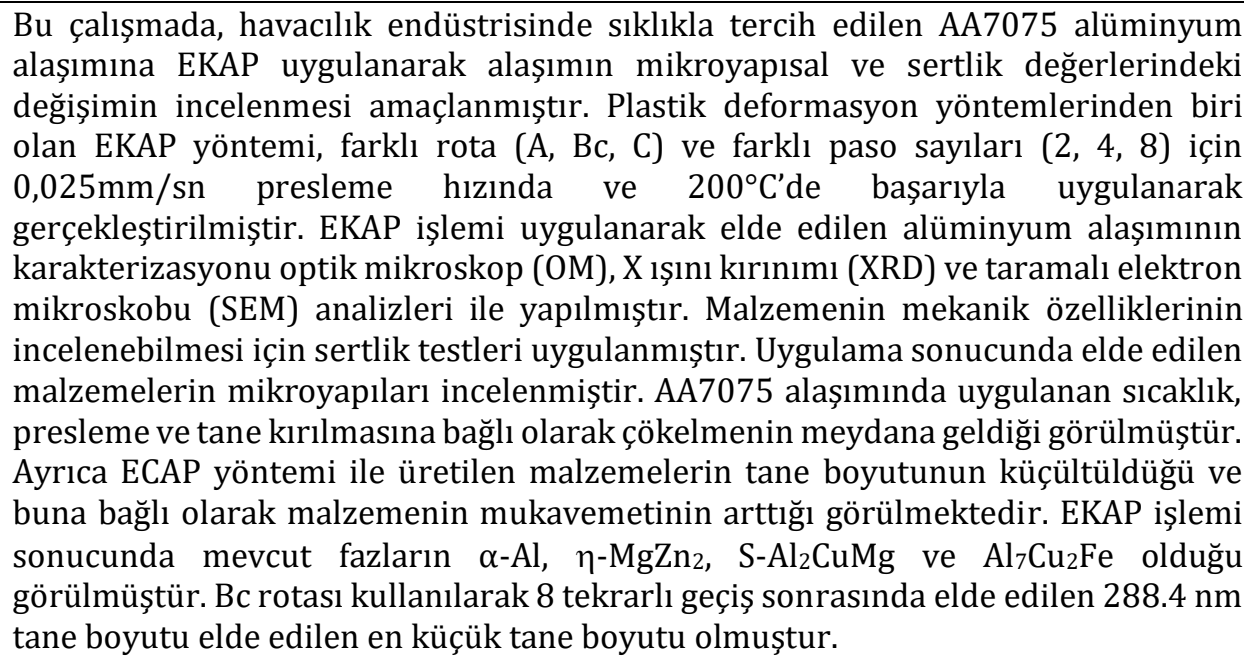 \\
\hline
\end{tabular}

Alıntı / Cite

Lule Senoz, G. M., Ozturk, D., (2021). Investigation of Microstructural and Hardness Changes of Aa7075 Alloy Processed by Ecap, Journal of Engineering Sciences and Design, 9(4), 1326-1338.

\footnotetext{
* ilgili yazar / Corresponding author: meltem.lule@atauni.edu.tr, +90-442-231-6039
} 


\begin{tabular}{l|l|l}
\hline Yazar Kimliği / Author ID (ORCID Number) & \multicolumn{3}{|l}{ Makale Süreci / Article Process } \\
\hline G.M. Lüle Şenöz, 0000-0003-0870-1269 & Başvuru Tarihi / Submission Date & 12.04 .2021 \\
D. Öztürk, 0000-0001-9592-6663 & Revizyon Tarihi / Revision Date & 13.09 .2021 \\
& Kabul Tarihi / Accepted Date & 14.09 .2021 \\
& Yayım Tarihi / Published Date & 20.12 .2021 \\
\hline
\end{tabular}

\section{Introduction}

Aluminum and its alloys are included in the metal and alloy group, which are used extensively in the industrial field due to their low production costs and light weight. As a result of the technological developments in the automotive sector, aviation, and food sector, it has become necessary to increase and improve the mechanical properties of these alloys. The high strength levels aimed at aluminum alloys are mainly achieved by precipitation hardening. The control of grain size in these alloys forms the basis of thermo-mechanical processes. It is well known that nanoscale materials produced by thermo-mechanical processes exhibit superior strength, hardness, electrical resistance, and specific thermal capacity values compared to their coarse-grained counterparts. This is because it is possible to increase and yield the strength of a material at low temperatures by reducing the grain size of the material through the standard Hall-Petch relationship.

The most common methods used to reduce grain size are severe plastic deformation methods. Among these methods, the equal channel angular pressing method is one of the topics that have attracted considerable attention recently, as it exposes cast materials to high plastic stresses without changing the cross section (Furukawa et al. 2001). The ECAP die is composed of two channels with identical rectangular cross sections connected through the intersection at a specific angle (Valiev and Langdon 2006). Very high shear stress can be obtained with multiple passes through a die without any change in billet dimensions. Thus, the formation of ultra-fine homogeneous grain structure is obtained. As a result, a very strong improvement of the microstructure down to the sub-micrometer level can be achieved (Valiev et al. 2000).

In the last decade, many metals and alloys including aluminum and its alloys (Li and Langdon 2000; Raab et al. 2004; Mao et al. 2005; Mckenzie et al. 2007; Xu and Langdon 2007; Roven et al. 2008; Hockauf et al. 2008; Meyer et al. 2008; Sha et al. 2009; Duan et al. 2010; Wang et al. 2011; Murashkin et al. 2013), magnesium and its alloys (Lapovok et al. 2008; Figueiredo and Langdon 2010; Janecek et al. 2010; Janecek et al. 2012; Silva et al. 2017), titanium and its alloysex (Semenova et al. 2008; Semenova et al. 2012; Sordi et al. 2012), copper (Zhang et al. 2008; Zhilyaev et al. 2008; Lugo et al. 2010; Wongsa-Ngam et al. 2013), zinc (Huang and Langdon 2002), nickel (Zhilyaev et al. 2003; Gubicza et al. 2007), iron (Sus-Ryszkowska et al. 2004), stainless steel (Niendorf et al. 2010; Ueno et al. 2011), and low carbon steel (Park et al. 2000; Sekban et al. 2017; Sekban 2020), have been successfully processed for the formation of nanostructured and ultrafine-grained (UFG) material by the ECAP technique.

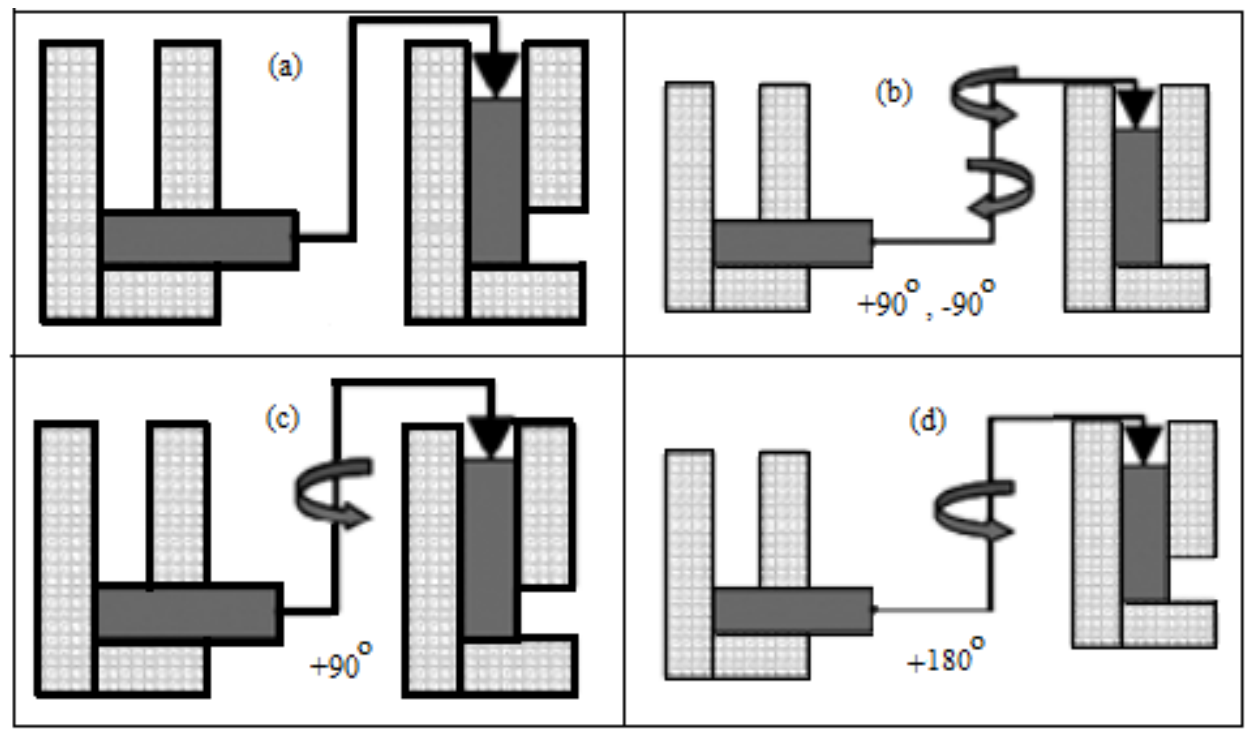

Figure 1. Rotation angles and directions for possible routes (a) Route $A$, (b) Route $B_{A}$, (c) Route $B_{C}$, (d) Route $C$ (Venkatachalam et al. 2010)

The most critical parameters in the ECAP process are the process route applied to the material and the number of passes (Furukawa et al. 1997; Malek et al. 2004). During the ECAP process, the material is rotated at certain angles to create a constantly changing sliding mechanism within the material with different routes applied. In the ECAP 
process, the deformation direction is obtained by rotating the sample at different angles $\left(0^{\circ}, 90^{\circ}\right.$, or $\left.180^{\circ}\right)$ counterclockwise or clockwise (Figure 1). Routes take a separate name for each direction and turn angle. Depending on the direction of rotation, the properties of the materials change, and the deformation amount can be distributed homogeneously. A geometric representation of the shear strain applied to the material before each pass and the directions of the shear sections according to the routes of the sample subjected to is shown in Figure 2.

Among these routes, the Bc route is the most suitable way to achieve superplasticity. It also results in a series of coaxial grains with high angle grain boundaries (Lee et al. 2003).

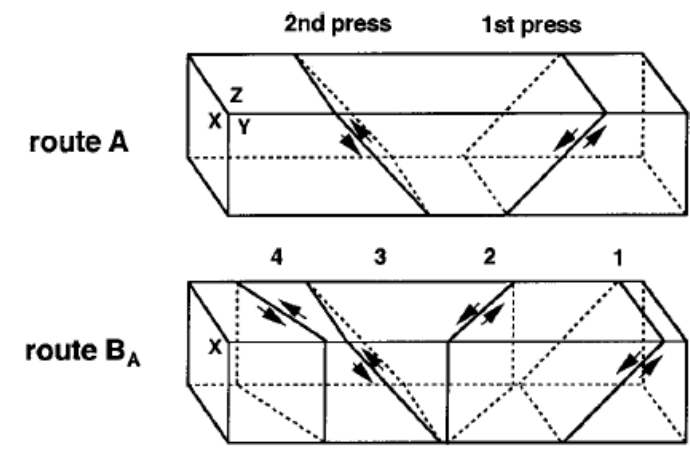

route $\mathbf{B}_{\mathrm{C}}$
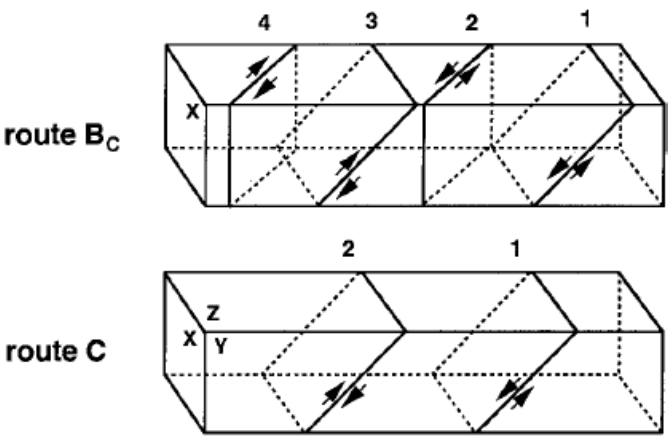

Figure 2. The shearing planes concerning processing rotations (Valiev and Langdon 2006)

During the ECAP process, the temperature is another important parameter that directly affects the yield stress of materials. Generally, it is more difficult for the material to undergo plastic deformation at low temperatures. Rising the pressing temperature increases the workability and deformation ability of the materials. Activation of additional shear planes with temperature provides convenience during plastic deformation of the material (OhIshi et al. 1998). Many studies explain the mechanical properties as well as the effect on microstructure at high temperatures with the ECAP technique in Al 7000 series alloys (Xu et al. 2003; Shaeri et al. 2016). However, hightemperature pressing can cause possible grain growth. In age-hardenable alloys such as AA7075, the formation of new phases, as well as the precipitates formed during the ECAP process, have a negative effect on the mechanical behavior of the material. Therefore, it is important to optimize the ECAP process at relatively warm temperatures.

The aim of this study to find the optimum ECAP parameters that meet the highest microhardness value and lowest grain size value at a relatively warm temperature. Characterization studies of the samples obtained by ECAP process applied at $200^{\circ} \mathrm{C}$ temperature and a pressing speed of $0.025 \mathrm{~mm} / \mathrm{sec}$ for different process routes (A, Bc, C) and the different number of passes $(2,4,8)$ were carried out. Hardness tests were applied to examine the mechanical properties of the material.

\section{Material and Method}

\subsection{Material}

A conventionally extruded Al-Zn-Mg alloy with a chemical composition of wt.\% of $89.7 \mathrm{Al}, 6.8 \mathrm{Zn}, 2.1 \mathrm{Mg}, 1.2 \mathrm{Cu}$, and $0.2 \mathrm{Cr}$ was cut to the rods with a diameter of $19.8 \mathrm{~mm}$ and length of $40 \mathrm{~mm}$. All samples were annealed for 1 hour at $420^{\circ} \mathrm{C}$ before the ECAP process. Thus, residual stress and intermetallic compounds caused by production in the sample were eliminated.

\subsection{ECAP Procedure}

The die used for ECAP processes and hydraulic compression press is shown in Figure 3. The processes were conducted at $200^{\circ} \mathrm{C}$ for different deformation routes $\left(\mathrm{A}, \mathrm{B}_{\mathrm{C}}, \mathrm{C}\right)$ up to 8 passes. Before the ECAP process, the die was kept at $200^{\circ} \mathrm{C}$ for 2 hours and the samples were kept for 15 minutes before each pass. Billets were lubricated with $\mathrm{MoS}_{2}$ to reduce friction between the die and sample during the process and then pressed using an ECAP solid die that has a channel angle of $\phi=120^{\circ}$ and corner curvature angle of $\psi=60^{\circ}$. The pressing speed applied for the whole ECAP process was $0.025 \mathrm{~mm} / \mathrm{s}$.

\subsection{Microstructure Characterization}

The microstructures of samples obtained by the ECAP process were characterized by using an X-ray diffractometer (XRD), optic microscope (OM), scanning electron microscopy (SEM), and grain size analyses. XRD measurements 
were performed to as-received and ECAPed samples to characterize and identify the alloy phases present by using Rigaku-2200 D/Max X-ray powder diffractometer with $\mathrm{Cu}$ Ka radiation. The generator set was $45 \mathrm{kV}, 40 \mathrm{~mA}$. The average grain size was calculated by using the Debye - Scherrer formula.

$$
\mathrm{D}=\frac{\boldsymbol{k} \cdot \lambda}{\boldsymbol{\beta} \cdot \boldsymbol{c o s} \theta}
$$

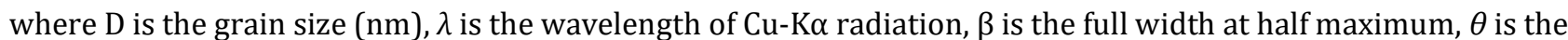
Bragg's angle, and $k$ is crystallite-shape constant. Calculations were carried on by accepting the value of $\mathrm{Cu}-\mathrm{K} \alpha$ radiation wavelength $(\lambda)$ as 1.54 and the crystallite-shape constant $(k)$ as 0.9 . The full width at half maximum (FWHM) was measured from strong intensity X-ray diffraction profiles by using PANalytical XPert-High Score Plus software. Also, PANalytical XPert-High Score Plus software was used to identify the phases.

To take images from the side of the samples, they were cut by Struers Accutom-5 Linear Precision Saw at a feed rate of $0.05 \mathrm{~mm} / \mathrm{s}$. The surface of the specimens was mechanically ground up to 2000 grit $\mathrm{SiC}$ paper, then polished using $1 \mu \mathrm{m}$ diamond paste with $0.05 \mu \mathrm{m}$ silica colloidal and then etched using an aqueous solution of Keller's reagent $\left(2.5 \mathrm{ml} \mathrm{HNO}_{3}+1.5 \mathrm{ml} \mathrm{HCl}+1.0 \mathrm{ml} \mathrm{HF}+95 \mathrm{ml}\right.$ distilled water $)$. After the metallographic processes, an optical microscope (LEICA DM 4000M: Metal Microscope) and SEM analysis were performed for microstructure examinations. Scanning electron microscope (SEM) studies were carried out using a JEOL JSM-6060 instrument equipped.

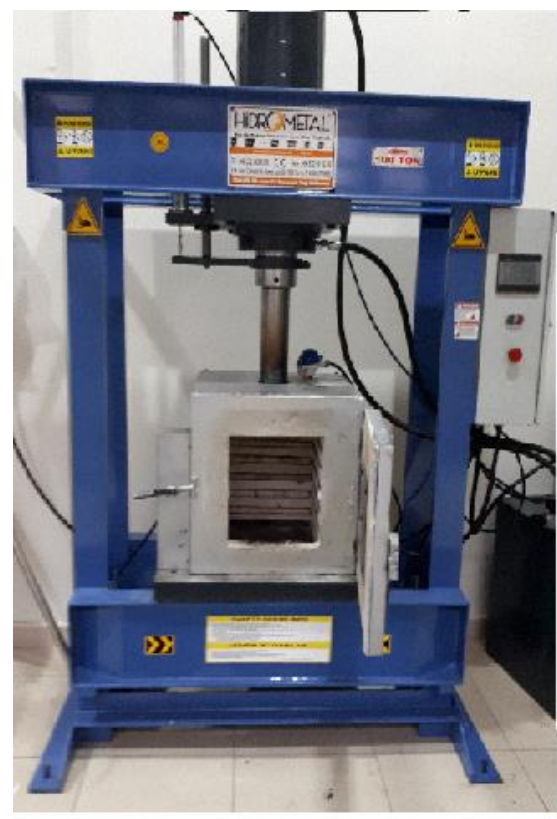

(a)

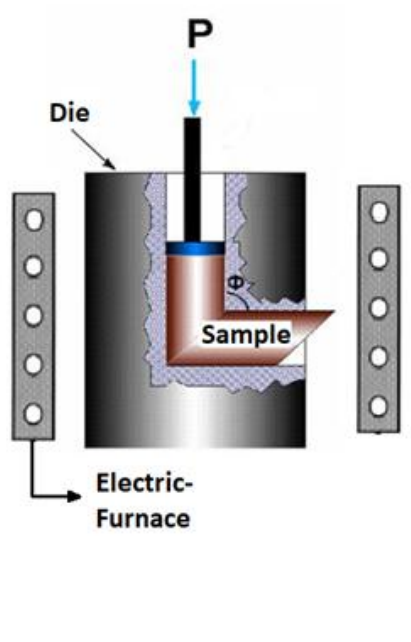

(b)

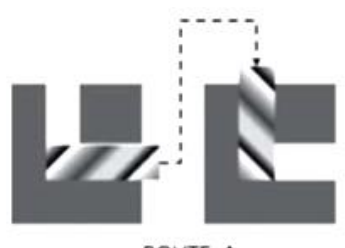

ROUTE A

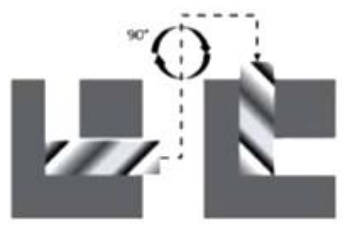

ROUTE $B_{C}$

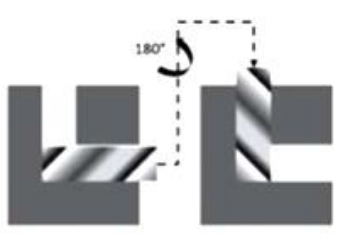

ROUTE C

(c)

Figure 3. Schematic ECAP mechanism (a) ECAP experimental setup, (b) ECAP system, (c) Schema ECAP of route A, Bc, and C

\subsection{Mechanical Testing}

Followed by the ECAP process, mechanical tests were performed using Wolpert Wilson-400 micro-hardness testing equipment comprising of a Vickers indenter. The load applied on the specimens was about $0.01 \mathrm{kgf}$. Each microhardness value reported in this study is obtained by taking the mean of at least five individual readings.

\section{Experimental Results}

Changes in microstructure and hardness values of AA7075 alloy produced with ECAP in the determined parameters were examined. During the ECAP process, deformations occurred in the samples, especially at the inner corner point where friction is intense. Studies have shown that as the number of passes increases, the grain size of the sample decreases, and thus its hardness increases. This situation causes the samples to be strained and break in the next pass.

Moreover, in the ECAP die, which is made of high-work tool steel with high wear resistance and high toughness, tears have occurred due to high friction and stresses between the material and the mold. The deformations and 
surface cracks that were seen on the sample have been removed by surface grinding in order not to cause any problems in the next pass. As the number of passes increased, the sample size was shortened due to the decrease in the grain size of the sample, the increase in density, and the deformations (Figure 4).

In the first examinations made on the samples, it was observed that different routes and a different number of passes caused different effects on the sample structure, and the loss of material due to fracture and cracking was especially high in the Bc route. These effects are thought to be caused by heterogeneous strains, different orientations, and dislocations caused by severe plastic deformation in the sample. In addition to dislocations, sample internal structure defects also trigger this situation (Saray et al. 2013).

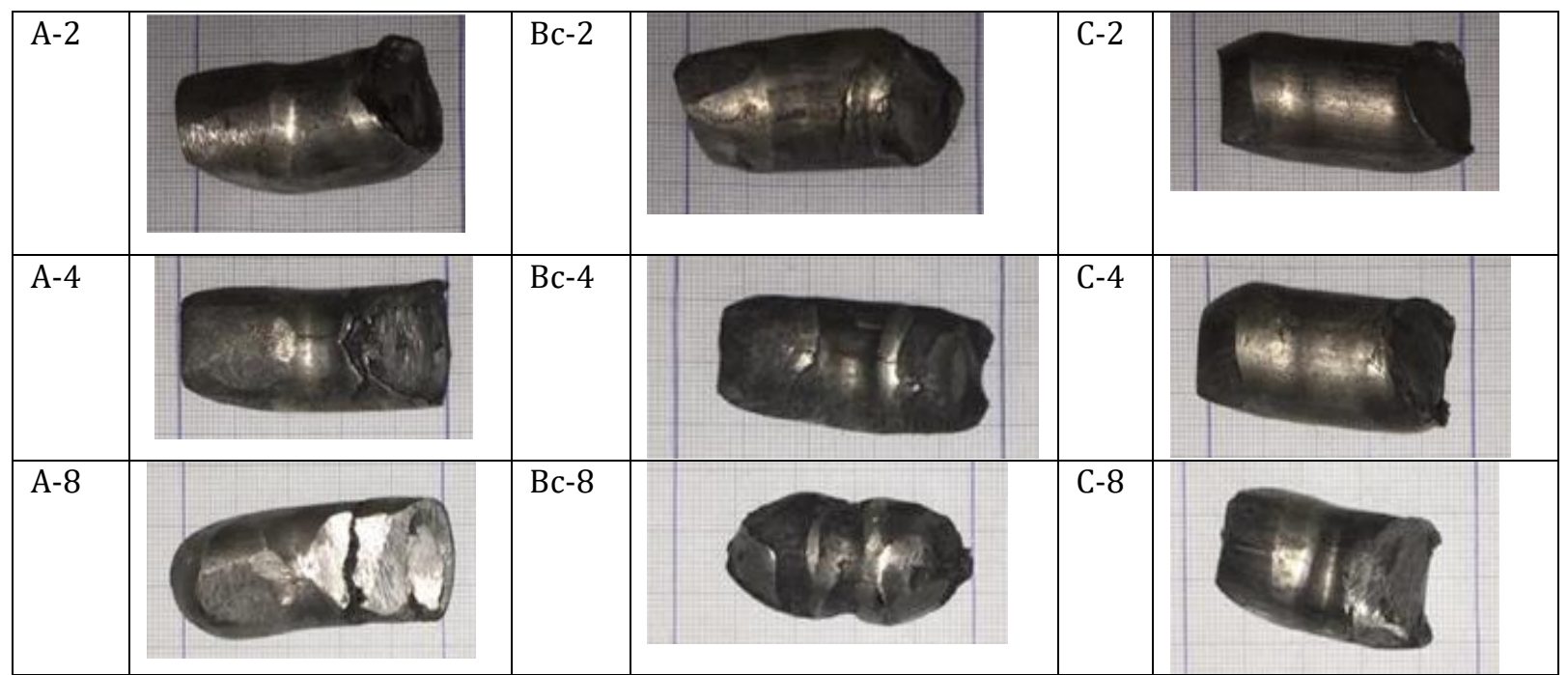

Figure 4. Samples produced by applying the ECAP process.

\subsection{XRD Analyses}

The enlarged XRD patterns of ECAPed specimens under various conditions were illustrated in Figure 5. As it is seen in Figure 4, the microstructure consists of $\alpha-\mathrm{Al}, \eta$ phase (MgZn2), and S phase (Al2CuMg and Al7 Cu2Fe). $\alpha-$ Al phase shows five highest intensity peaks, namely, (111), (200), (220), (311), and (222). It was observed that the GP regions formed with the precipitation hardening consisted of the $\eta$ phase. These precipitates form an intermetallic compound, showing GP regions (GPZs) with a broad peak noticed at 2 theta $=20^{\circ}$. Other weak peaks also observed at 2 theta between $40^{\circ}$ and $45^{\circ}$ may be present due to the transition hexagonal $\eta^{\prime}$ phase. This might be because of the peak positions which are at slightly lower angles than those of the hexagonal $\eta$ phase. Besides, their lattice parameters are also a little different from those of the $\eta$ phase. The formation of such phases was thought to be due to the high temperature produced during the processes (Zhao et al. 2004; Cardoso et al. 2014). It is well known that these phases formed in the structure improve the mechanical properties of the structure (Van Horn 1968; Baker 1990; Williams and Starke 2003). After obtaining data from XRD analysis, the crystallite size of the ECAPed samples has been calculated by using Debye-Scherrer Equation. Sharp and strong diffractions in the range of $2 \theta=35-45^{\circ}$ were determined by the software and FWHM (full width at half maximum), full width at half height) values were calculated for each peak. 


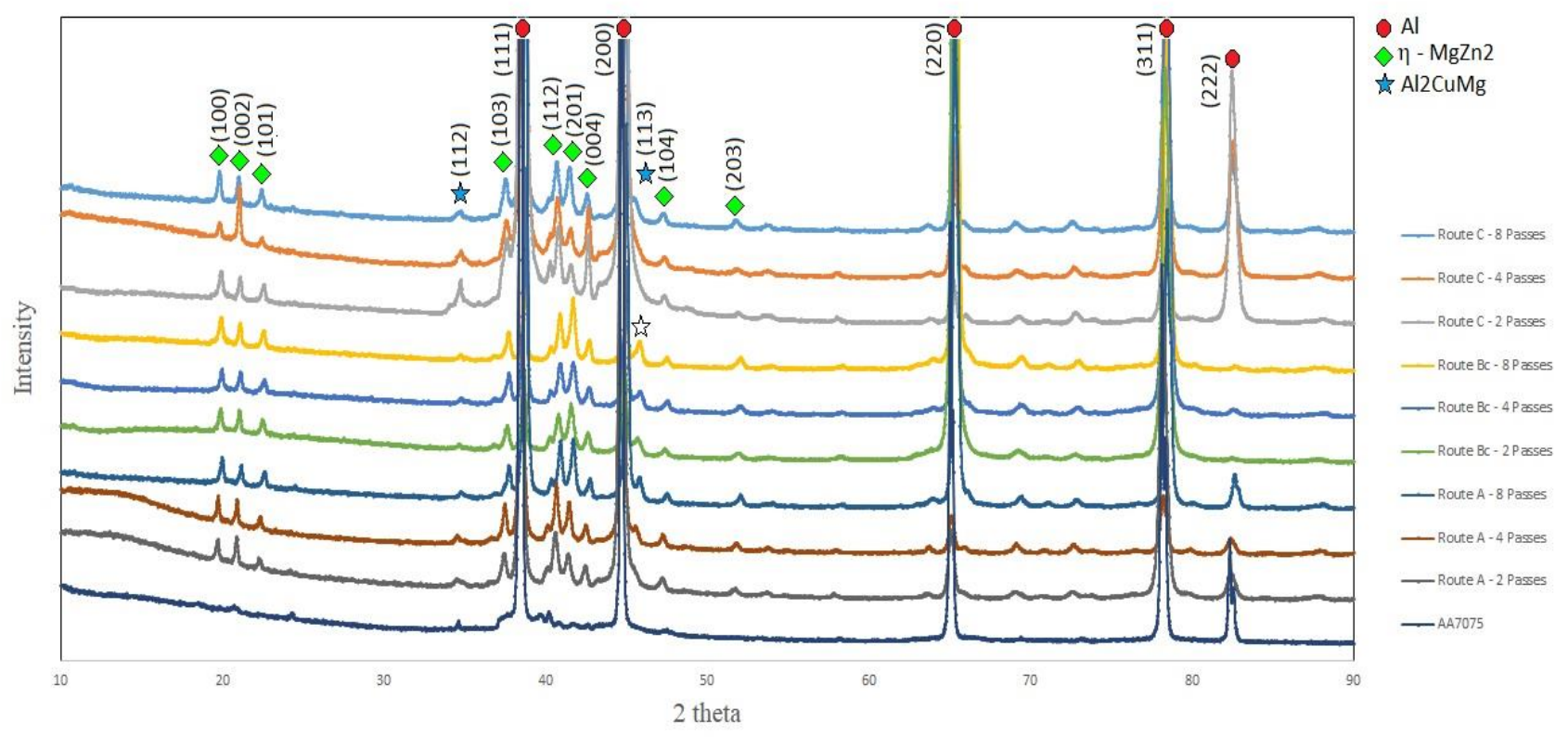

Figure 5. XRD pattern of ECAPed samples

The grain size of each sample was determined by taking the average of the calculated grain sizes of the phases determined for that sample. Grain size values calculated using the Debye-Scherrer equation are shown in Table 1. In general, a decrease in the grain size of the ECAP applied samples is observed.

Table 1. Average Grain Sizes of ECAPed Samples

\begin{tabular}{|l|l|}
\hline ECAP Process & $\begin{array}{l}\text { GRAIN SIZE } \\
\text { (nm) }\end{array}$ \\
\hline Non- ECAPed & 660 \\
\hline Route A - 2 Passes & 328 \\
\hline Route A - 4 Passes & 383.2 \\
\hline Route A - 8 Passes & 407.6 \\
\hline Route Bc - 2 Passes & 398.8 \\
\hline Route Bc - 4 Passes & 368.2 \\
\hline Route Bc - 8 Passes & 288.4 \\
\hline Route C - 2 Passes & 396.2 \\
\hline Route C - 4 Passes & 324.6 \\
\hline Route C - 8 Passes & 342.6 \\
\hline
\end{tabular}

The changes in average grain size after the ECAP process are given in Figure 6. It has been observed that the grain size measured in each pass changes in the $\mathrm{A}, \mathrm{Bc}$, and $\mathrm{C}$ routes as the number of passes increases. The decrease in the grain size of the samples applied in the Bc route was evidently seen as the number of passes increased, but the grain size of the samples applied in the A route increased as the number of passes increased. The increase observed in the grain size of the samples applied the A route is thought to be due to the recrystallization of the grains and the high-angle grain boundaries not increasing sufficiently due to the absence of deformation in the z plane (Valiev and Langdon 2006). It is thought that the reason for the decrease in the grain size of the samples, on which route $\mathrm{C}$ was applied, up to 4 passes and the increase observed at the end of 8 passes, is because the sliding continues in the same plane in each pass through the mold. In Route $C$, there is no deformation in the $\mathrm{z}$ plane (Valiev and Langdon 2006) 


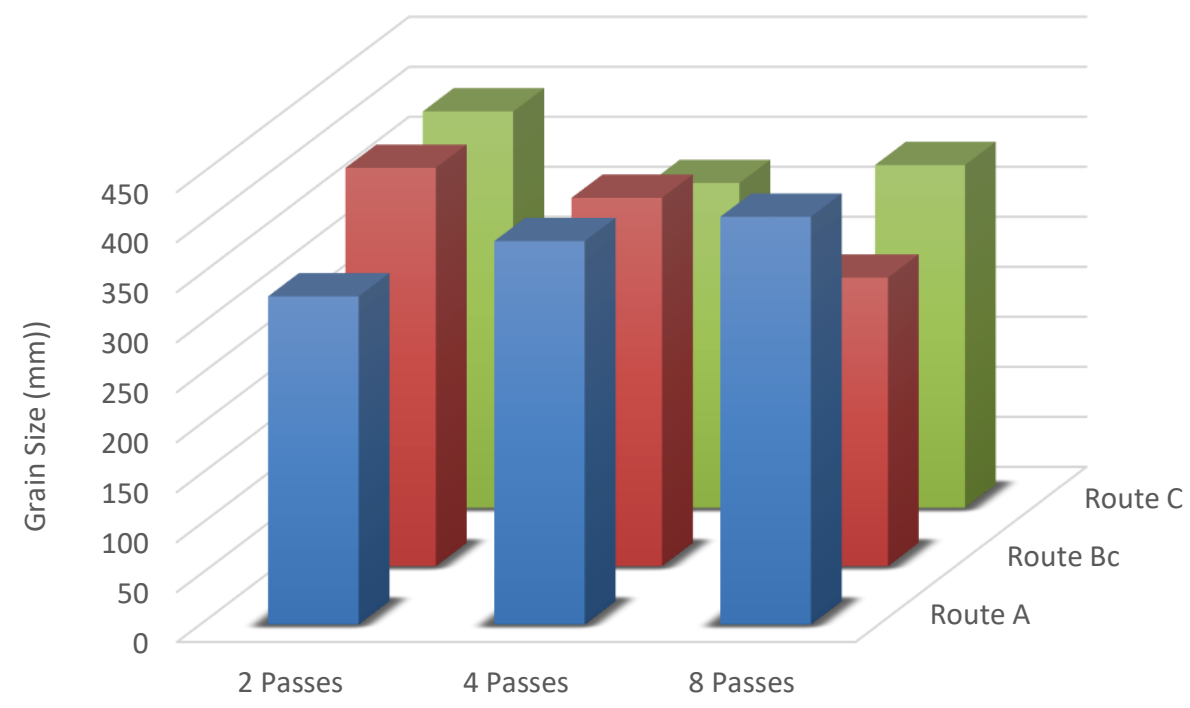

Figure 6. Comparison of grain sizes in different routes and passes

\subsection{Optical Microscope}

The optical microscope images of the ECAPed samples were given in Figure 7. When the optical microscope images are examined, it has been observed that the grains tend towards the deformation direction with the effect of the applied deformation. As a result of the ECAP process repeated in each route and the different number of passes, it is explicitly seen that the increase in grain reduction occurs gradually as the number of passes increases. The presence of irregularities in the structure can be explained by the presence of different grain sizes and the inability to achieve full homogenization within the structure. When examining the samples whose grain size was calculated theoretically with XRD graphics, a reduction in the grain size of the sample was observed as a result of the ECAP process by applying the A route. It is thought that as the number of passes increases in route A, the increase in grain size is due to the dynamic recrystallization of the applied temperature during the ECAP process. As a result of the ECAP operations performed on the Bc route, it was observed that the sample, which was applied for 8 passes, gave the smallest grain size value. Since the grain size is the lowest among all samples, the direction of extrusion was almost not visible. As a result of the ECAP operations performed on the $C$ route, it was observed that the orientation frequency due to deformation was the most significant in the sample applied 4 passes.

\subsection{SEM/EDS (Scanning Electron Microscopy) Analysis}

It is known that the grain size decreases after plastic deformation and the precipitates that occur as a result of heat treatment cause changes in the strength of the material. It was previously determined in XRD analysis that the precipitates formed as a result of the ECAP process in $\mathrm{Al}-\mathrm{Mg}-\mathrm{Zn}$ alloys are $\mathrm{MgZn}_{2}, \mathrm{Al}_{2} \mathrm{CuMg}$, and $\mathrm{Al}_{7} \mathrm{Cu}_{2} \mathrm{Fe}_{\text {. When }}$ the SEM / EDS analysis for each sample is examined, it is seen that the Al7Cu2Fe precipitate, whose brightness can be unambivalently observed, shows an irregular shape, while the $\mathrm{Al}_{2} \mathrm{CuMg}$ and $\mathrm{MgZn}_{2}$ phases have a spherical shape. 

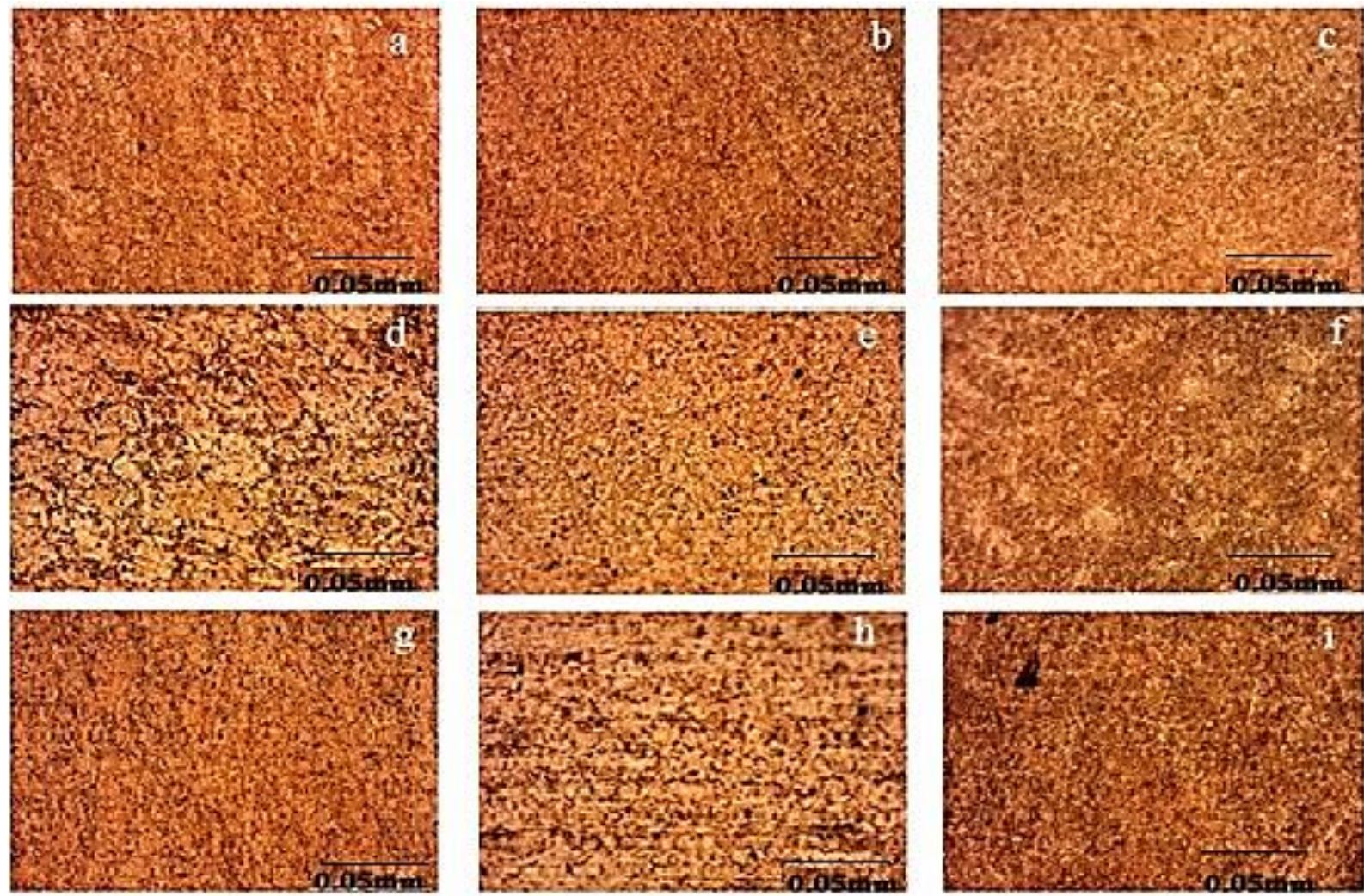

Figure 7. Optical microscope images of different routes and passes (a: Route A/2, b: Route A/4, c: Route A/8, d: Route Bc/2, e: Route $\mathrm{Bc} / 4, \mathbf{f}$ : Route $\mathrm{Bc} / 8$, g: Route $\mathrm{C} / 2$, h: Route $\mathrm{C} / 4$, i: Route $\mathrm{C} / 8$ )

SEM images of samples that have been applied ECAP in different passes are given in Figures 8, 9, and 10. When the EDS analysis results are examined, it is seen that the elements obtained following the assumption of the precipitates formed are $\mathrm{Al}, \mathrm{Mg}, \mathrm{Zn}$, and $\mathrm{Cu}$.

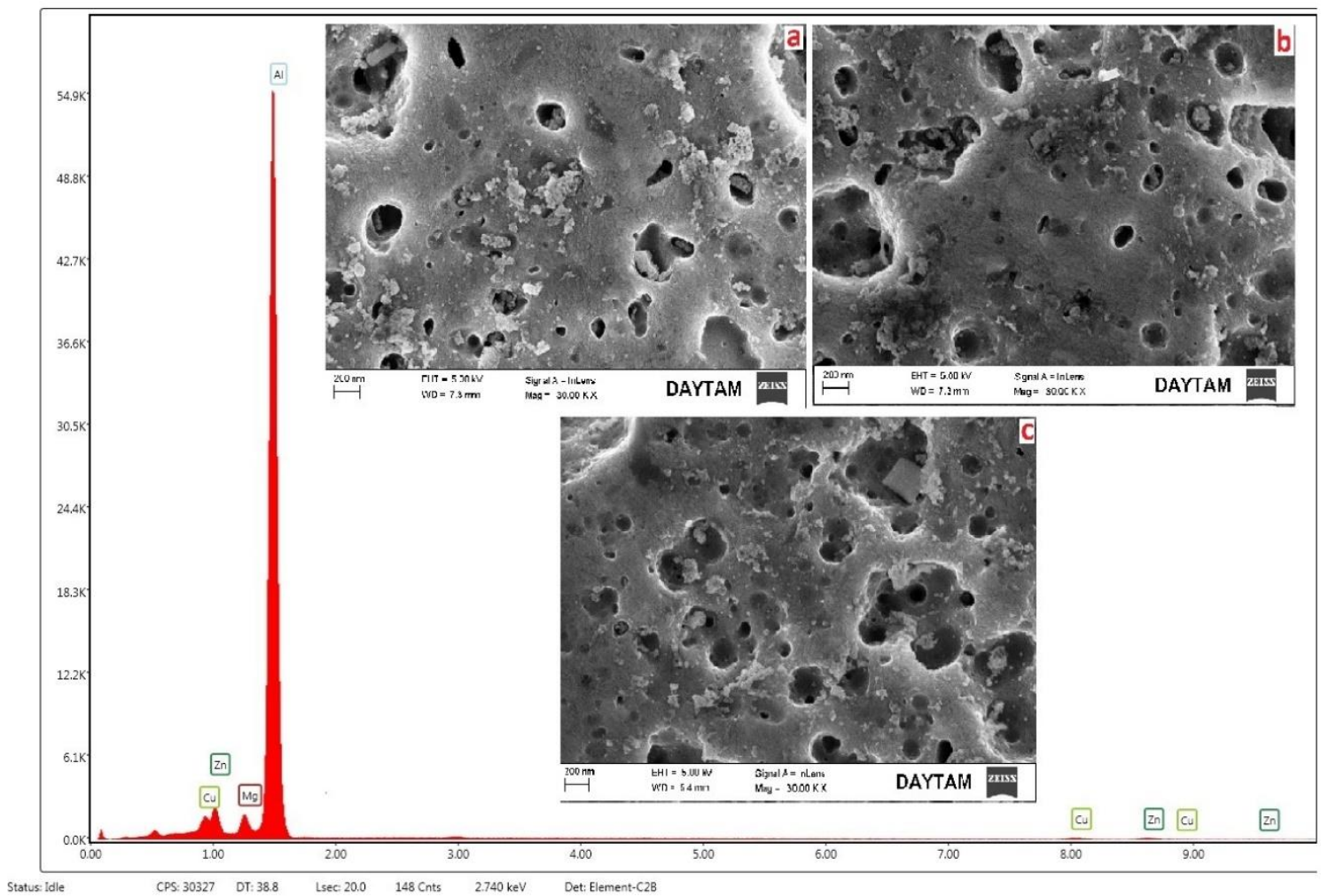

Figure 8. SEM /EDS images of ECAPed samples at Route A (a:2 passes, b:4 passes, c:8 passes) 


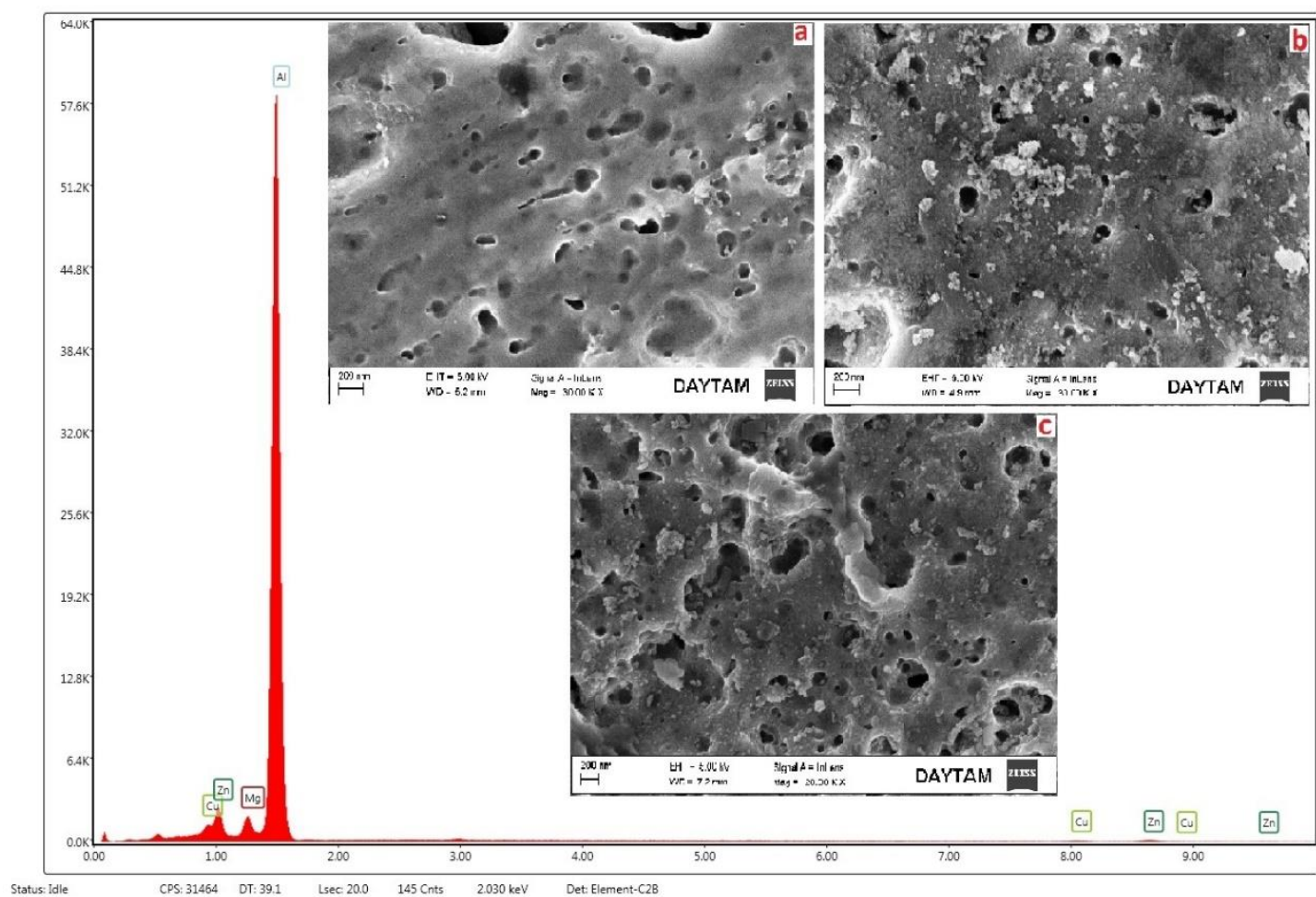

Figure 9. SEM /EDS images of ECAPed samples at Route Bc (a:2 passes, b:4 passes, c:8 passes)

It is known that the temperature and severe plastic deformation during the ECAP process can form intermetallic compounds in the structure. The dense and regular microstructure of the sub-grains formed by the effect of severe plastic deformation may be affected by temperature, route, and number of passes and leave their place to coarsegrained structures. When the SEM/EDS images of the samples applied with the Bc route are examined, it is seen that the coarse grains, as well as the fine grains in the AA7075 alloy, are formed homogeneously in the structure during the process. When the SEM/EDS images of the samples applied A and C routes are examined, it is seen that this distribution is not homogeneous.

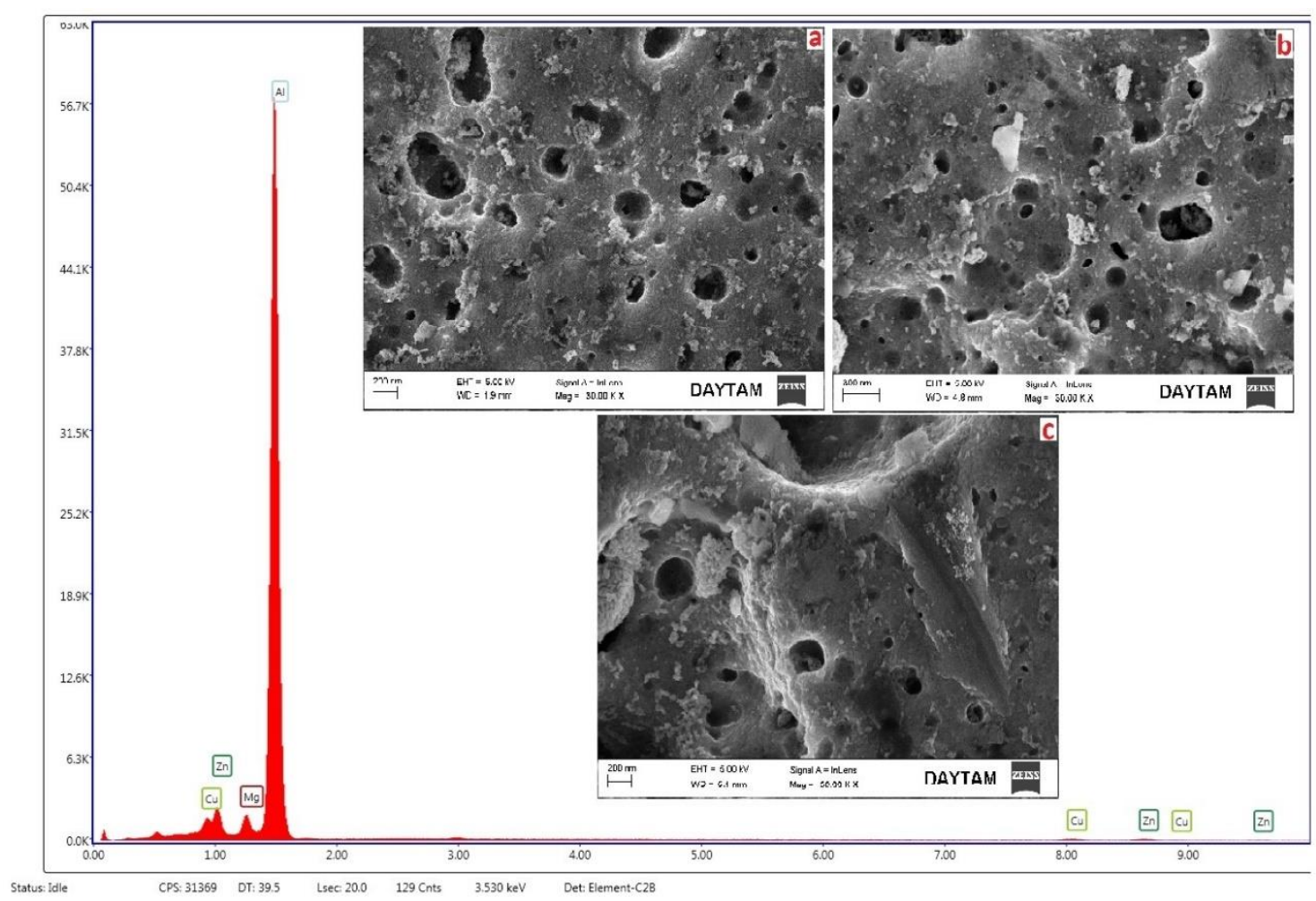

Figure 10. SEM images of ECAPed samples at Route C (a: 2 passes, b: 4 passes, c: 8 passes) 
In elongated grains of ECAP-treated material, the dislocation density increases during processing. This is due to plastic deformation by the sliding mechanism that occurs during the ECAP process (Zheng et al. 2002). It is stated in the previous studies that the structure is not homogeneous, anisotropic and its properties change mostly due to deformation-related reasons after the transitions in the ECAP process. After repeated ECAP processes, aluminum materials show homogeneous particle size distribution. The number of passes repeating up to achieve a homogeneous microstructure. But the microstructure is still anisotropic (Liu et al. 2003; Saravanan et al. 2006). In the ECAP process, changes occur in the material characteristics depending on the rotational directions of the material. Bc route is the optimum route in which microstructural evolution occurs mostly (Furukawa et al. 1997; Langdon 2013).

Similar results were obtained in this study. With the microhardness analysis, it is observed that the hardness values of the samples showing heterogeneous structure ( $A$ and $C$ route applied) are lower than the hardness values of the samples showing homogeneous structure (Bc route applied). These results give information about the homogenization in the structure and prove the accuracy of the results.

\subsection{Mechanical Testing}

The hardness measurement results of non-ECAPed and ECAPed samples are given in Table 2. By severe plastic deformation, an increase in the density of dislocation occurs due to the stresses in the internal structure of the material. The precipitations detected in XRD and SEM/EDS analyzes are harder than the main matrix phase and cause the hardness of the material to increase by preventing the dislocation movement during the severe plastic deformation process. When the microhardness values were examined, it was seen that the highest hardness value was obtained in the Bc course and with 8 passes. The hardness decrease occurring in the A route can be explained by the recrystallization of the grains in the material and the increase of the grain size accordingly. In the $\mathrm{C}$ route, the highest hardness value was obtained with 4 passes, and when the number of passes was increased, a decrease in the hardness value was observed in 8 passes as a result of the recrystallization of the grains and the increase in grain size. The grain boundaries observed in multi-grain materials restrict the movement of dislocations and cause the material to become stronger. Conversely, all kinds of factors that will facilitate dislocation movements will make plastic deformation easier.

Table 2. Micro-hardness (HV) values of non-ECAPed and ECAPed samples

\begin{tabular}{|l|l|}
\hline ECAP Process & $\begin{array}{l}\text { Microhardness } \\
(\mathbf{H V})\end{array}$ \\
\hline Non- ECAPed & 95 \\
\hline Route A - 2 Passes & 149 \\
\hline Route A - 4 Passes & 137 \\
\hline Route A - 8 Passes & 127 \\
\hline Route Bc - 2 Passes & 129 \\
\hline Route Bc - 4 Passes & 142 \\
\hline Route Bc - 8 Passes & 184 \\
\hline Route C - 2 Passes & 134 \\
\hline Route C - 4 Passes & 152 \\
\hline Route C - 8 Passes & 146 \\
\hline
\end{tabular}

The grain boundary in the material can be controlled by thermo-mechanical treatments, heat treatments, or microalloy. As the grains get smaller with thermo-mechanical processes, the strength of the material increases as the amount of grain boundary per unit volume increases.

With the deformation that occurs during the ECAP process, dislocations moving on the same slip plane accumulate near the grain boundary and form a dislocation pile-up. As new ones are added to this dislocation density, the trailing ones apply force to the dislocation stacks in the front, allowing the leading dislocations to move onto the other grain and continue to slide. Thus, together with the definite improvement in the deformation ability of the material, it causes an increase in the strength values of the material. Comparison of grain sizes in different routes and passes are given in Figure 11. 


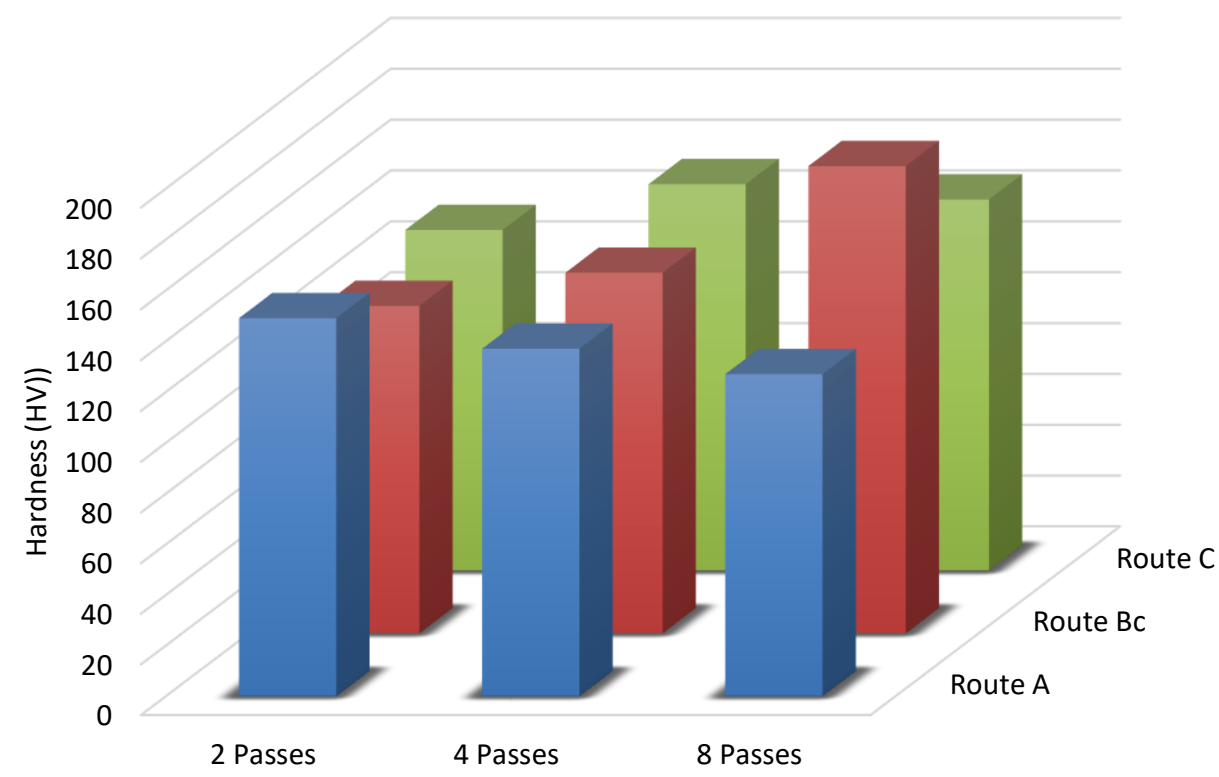

Figure 11. Comparison of hardness in different route and pass

\section{Result and Discussion}

The XRD graphs of the samples that were applied ECAP process in different routes and passes were examined and it was determined that the phases present in $\mathrm{AA} 7075$ alloy were $\alpha-\mathrm{Al}, \eta-\mathrm{MgZn}_{2}, \mathrm{~S}-\mathrm{Al}_{2} \mathrm{CuMg}$, and $\mathrm{Al}_{7} \mathrm{Cu}_{2} \mathrm{Fe}$. The grain size of $288.4 \mathrm{~nm}$ obtained after 8 repeated passes using the Bc route was the smallest grain size obtained. SEM/EDS analyzes were examined for each sample and it was observed that the $\mathrm{Al}_{7} \mathrm{Cu}_{2} \mathrm{Fe}$ precipitate, whose brightness was visible, showed an irregular shape, and the $\mathrm{Al}_{2} \mathrm{CuMg}$ and $\mathrm{MgZn}_{2}$ phases had a spherical shape. According to the hardness measurement results of non-ECAPed and ECAPed samples, it was seen that the highest hardness value was obtained in the Bc course and with 8 passes. This increase in hardness is thought to be the result of the precipitates (GPZ, phase, and S phase) formed in the material after the ECAP process and these precipitates prevent the dislocation movement.

\section{Acknowledgment}

This work was supported by the Atatürk University Scientific Research Projects Coordination Unit. Project Number: FBA-2020-8351.

\section{Conflict of Interest}

No conflict of interest was declared by the authors.

\section{References}

Baker, H. 1990. Handbook-Alloy Phase Diagrams ASM International, 3279-337. Doi:

Cardoso, K. R., Munoz-Morris, M. A., Lieblich, M., and Morris, D. 2014. Effect of Equal Channel Angular Pressing (ECAP) on Microstructure and Properties of Al-FeAlCr Intermetallic Phase Composites, Materials Research-Ibero-American Journal of Materials, 17(3), 775-780. Doi: 10.1590/S1516-14392014005000029

Duan, Z. C., Liao, X. Z., Kawasaki, M., Figueiredo, R. B., and Langdon, T. G. 2010. Influence of high-pressure torsion on microstructural evolution in an Al-Zn-Mg-Cu alloy, Journal of Materials Science, 45(17), 4621-4630. Doi: 10.1007/s10853-010-4400-0.

Figueiredo, R. B., and Langdon, T. G. 2010. Grain refinement and mechanical behavior of a magnesium alloy processed by ECAP, Journal of Materials Science, 45(17), 4827-4836. Doi: 10.1007/s10853-010-4589-y.

Furukawa, M., Berbon, P. B., Horita, Z., Nemoto, M., Tsenev, N. K., Valiev, R. Z., and Langdon, T. G. 1997. Production of ultrafinegrained metallic materials using an intense plastic straining technique, Towards Innovation in Superplasticity I, 233 2177-184. Doi: 10.4028/www.scientific.net/MSF.233-234.177.

Furukawa, M., Horita, Z., and Langdon, T. G. 2001. Developing ultrafine grain sizes using severe plastic deformation, Advanced Engineering Materials, 3(3), 121-125. Doi: 10.1002/1527-2648(200103)3:3<121::AID-ADEM121>3.0.CO;2-V.

Gubicza, J., Chinh, N. Q., Csanadi, T., Langdon, T. G., and Ungar, T. 2007. Microstructure and strength of severely deformed fcc metals, Materials Science and Engineering a-Structural Materials Properties Microstructure and Processing, 462(12), 86-90. Doi: 10.1016/j.msea.2006.02.455. 
Hockauf, M., Meyer, L. W., Nickel, D., Alisch, G., Lampke, T., Wielage, B., and Kruger, L. 2008. Mechanical properties and corrosion behaviour of ultrafine-grained AA6082 produced by equal-channel angular pressing, Journal of Materials Science, 43(23-24), 7409-7417. Doi: 10.1007/s10853-008-2724-9.

Huang, Y., and Langdon, T. G. 2002. Characterization of deformation processes in a Zn-22\% Al alloy using atomic force microscopy, Journal of Materials Science, 37(23), 4993-4998. Doi: Doi 10.1023/A:1021071228521.

Janecek, M., Cizek, J., Gubicza, J., and Vratna, J. 2012. Microstructure and dislocation density evolutions in MgAlZn alloy processed by severe plastic deformation, Journal of Materials Science, 47(22), 7860-7869. Doi: 10.1007/s10853-0126538-4.

Janecek, M., Yi, S., Kral, R., Vratna, J., and Kainer, K. U. 2010. Texture and microstructure evolution in ultrafine-grained AZ31 processed by EX-ECAP, Journal of Materials Science, 45(17), 4665-4671. Doi: 10.1007/s10853-010-4675-1.

Langdon, T. G. 2013. Twenty-five years of ultrafine-grained materials: Achieving exceptional properties through grain refinement, Acta Materialia, 61(19), 7035-7059. Doi: 10.1016/j.actamat.2013.08.018.

Lapovok, R., Estrin, Y., Popov, M. V., Rundell, S., and Williams, T. 2008. Enhanced superplasticity of magnesium alloy AZ31 obtained through equal-channel angular pressing with back-pressure, Journal of Materials Science, 43(23-24), 73727378. Doi: 10.1007/s10853-008-2685-z.

Lee, S., Furukawa, M., Horita, Z., and Langdon, T. G. 2003. Developing a superplastic forming capability in a commercial aluminum alloy without scandium or zirconium additions, Materials Science and Engineering a-Structural Materials Properties Microstructure and Processing, 342(1-2), 294-301. Doi: 10.1016/S0921-5093(02)00319-2.

Li, Y., and Langdon, T. G. 2000. Equal-channel angular pressing of an Al-6061 metal matrix composite, Journal of Materials Science, 35(5), 1201-1204. Doi: Doi 10.1023/A:1004740504619.

Liu, T., Zhang, W., Wu, S. D., Jiang, C. B., Li, S. X., and Xu, Y. B. 2003. Mechanical properties of a two-phase alloy Mg-8\%Li-1\%Al processed by equal channel angular pressing, Materials Science and Engineering a-Structural Materials Properties Microstructure and Processing, 360(1-2), 345-349. Doi: 10.1016/S0921-5093(03)00494-5.

Lugo, N., Llorca, N., Sunol, J. J., and Cabrera, J. M. 2010. Thermal stability of ultrafine grains size of pure copper obtain ed by equal-channel angular pressing, Journal of Materials Science, 45(9), 2264-2273. Doi: 10.1007/s10853-009-4139-7.

Malek, P., Cieslar, M., and Islamgaliev, R. K. 2004. The influence of ECAP temperature on the stability of Al-Zn-Mg-Cu alloy, Journal of Alloys and Compounds, 378(1-2), 237-241. Doi: 10.1016/j.jallcom.2003.11.161.

Mao, J., Kang, S. B., and Park, J. O. 2005. Grain refinement, thermal stability and tensile properties of 2024 aluminum alloy after equal-channel angular pressing, Journal of Materials Processing Technology, 159(3), 314-320. Doi: 10.1016/j.jmatprotec.2004.05.020.

Mckenzie, P. W. J., Lapovok, R., and Estrin, Y. 2007. The influence of back pressure on ECAP processed. AA 6016: Modeling and experiment, Acta Materialia, 55(9), 2985-2993. Doi: 10.1016/j.actamat.2006.12.038.

Meyer, L. W., Sommer, K., Halle, T., and Hockauf, M. 2008. Crack growth in ultrafine-grained AA6063 produced by equal-channel angular pressing, Journal of Materials Science, 43(23-24), 7426-7431. Doi: 10.1007/s10853-008-2725-8.

Murashkin, M. Y., Sabirov, I., Kazykhanov, V. U., Bobruk, E. V., Dubravina, A. A., and Valiev, R. Z. 2013. Enhanced mechanical properties and electrical conductivity in ultrafine-grained Al alloy processed via ECAP-PC, Journal of Materials Science, 48(13), 4501-4509. Doi: 10.1007/s10853-013-7279-8.

Niendorf, T., Rubitschek, F., Maier, H. J., Canadinc, D., and Karaman, I. 2010. On the fatigue crack growth-microstructure relationship in ultrafine-grained interstitial-free steel, Journal of Materials Science, 45(17), 4813-4821. Doi: 10.1007/s10853-010-4511-7.

Oh-Ishi, K., Horita, Z., Furukawa, M., Nemoto, M., and Langdon, T. G. 1998. Communications - Optimizing the rotation conditions for grain refinement in equal-channel angular pressing, Metallurgical and Materials Transactions a-Physical Metallurgy and Materials Science, 29(7), 2011-2013. Doi: 10.1007/s11661-998-0027-z.

Park, K. T., Kim, Y. S., Lee, J. G., and Shin, D. H. 2000. Thermal stability and mechanical properties of ultrafine grained low carbon steel, Materials Science and Engineering a-Structural Materials Properties Microstructure and Processing, 293(1-2), 165-172. Doi: 10.1016/S0921-5093(00)01220-X.

Raab, G. J., Valiev, R. Z., Lowe, T. C., and Zhu, Y. T. 2004. Continuous processing of ultrafine grained Al by ECAP-Conform, Materials Science and Engineering a-Structural Materials Properties Microstructure and Processing, 382(1-2), 30-34. Doi: 10.1016/j.msea.2004.04.021.

Roven, H. J., Liu, M. P., and Werenskiold, J. C. 2008. Dynamic precipitation during severe plastic deformation of an Al-Mg-Si aluminium alloy, Materials Science and Engineering a-Structural Materials Properties Microstructure and Processing, 483-8454-58. Doi: 10.1016/j.msea.2006.09.142.

Saravanan, M., Pillai, R. M., Pai, B. C., Brahmakumar, M., and Ravi, K. R. 2006. Equal channel angular pressing of pure aluminium - an analysis, Bulletin of Materials Science, 29(7), 679-684. Doi: -.

Saray, O., Purcek, G., Karaman, I., and Maier, H. J. 2013. Formability of Ultrafine-Grained Interstitial-Free Steels, Metallurgical and Materials Transactions a-Physical Metallurgy and Materials Science, 44a(9), 4194-4206. Doi: 10.1007/s11661013-1781-0

Sekban, D. M. 2020. Eș Kanallı Açısal Presleme (EKAP) Uygulanan Gemi İnșa Çeliğinin İçyapı ve Mekanik Özelliklerinin İncelenmesi, Mühendislik Bilimleri ve Tasarım Dergisi, 8(1), 240 -251. Doi: 10.21923/jesd.570536

Sekban, D. M., Aktarer, S. M., Zhang, H., Xue, P., Ma, Z. Y., and Purcek, G. 2017. Microstructural and Mechanical Evolution of a Low Carbon Steel by Friction Stir Processing, Metallurgical and Materials Transactions a-Physical Metallurgy and Materials Science, 48a(8), 3869-3879. Doi: 10.1007/s11661-017-4157-z.

Semenova, I. P., Polyakov, A. V., Raab, G. I., Lowe, T. C., and Valiev, R. Z. 2012. Enhanced fatigue properties of ultrafine-grained Ti rods processed by ECAP-Conform, Journal of Materials Science, 47(22), 7777-7781. Doi: 10.1007/s10853-0126675-9.

Semenova, I. P., Valiev, R. Z., Yakushina, E. B., Salimgareeva, G. H., and Lowe, T. C. 2008. Strength and fatigue properties enhancement in ultrafine-grained Ti produced by severe plastic deformation, Journal of Materials Science, 43(23-24), 7354-7359. Doi: 10.1007/s10853-008-2984-4 
Sha, G., Wang, Y. B., Liao, X. Z., Duan, Z. C., Ringer, S. P., and Langdon, T. G. 2009. Influence of equal-channel angular pressing on precipitation in an Al-Zn-Mg-Cu alloy, Acta Materialia, 57(10), 3123-3132. Doi: 10.1016/j.actamat.2009.03.017.

Shaeri, M. H., Shaeri, M., Ebrahimi, M., Salehi, M. T., and Seyyedein, S. H. 2016. Effect of ECAP temperature on microstructure and mechanical properties of Al-Zn-Mg-Cu alloy, Progress in Natural Science-Materials International, 26(2), 182-191. Doi: 10.1016/j.pnsc.2016.03.003.

Silva, C. L. P., Oliveira, A. C., Costa, C. G. F., Figueiredo, R. B., Leite, M. D., Pereira, M. M., Lins, V. F. C., and Langdon, T. G. 2017. Effect of severe plastic deformation on the biocompatibility and corrosion rate of pure magnesium, Journal of Materials Science, 52(10), 5992-6003. Doi: 10.1007/s10853-017-0835-x.

Sordi, V. L., Ferrante, M., Kawasaki, M., and Langdon, T. G. 2012. Microstructure and tensile strength of grade 2 titanium processed by equal-channel angular pressing and by rolling, Journal of Materials Science, 47(22), 7870-7876. Doi: 10.1007/s10853-012-6593-x.

Sus-Ryszkowska, M., Wejrzanowski, T., Pakiela, Z., and Kurzydlowski, K. J. 2004. Microstructure of ECAP severely deformed iron and its mechanical properties, Materials Science and Engineering a-Structural Materials Properties Microstructure and Processing, 369(1-2), 151-156. Doi: 10.1016/j.msea.2003.10.318.

Ueno, H., Kakihata, K., Kaneko, Y., Hashimoto, S., and Vinogradov, A. 2011. Nanostructurization assisted by twinning during equal channel angular pressing of metastable 316L stainless steel, Journal of Materials Science, 46(12), 4276-4283. Doi: $10.1007 / \mathrm{s} 10853-011-5303-4$

Valiev, R. Z., Islamgaliev, R. K., and Alexandrov, I. V. 2000. Bulk nanostructured materials from severe plastic deformation, Progress in Materials Science, 45(2), 103-189. Doi: 10.1016/S0079-6425(99)00007-9.

Valiev, R. Z., and Langdon, T. G. 2006. Principles of equal-channel angular pressing as a processing tool for grain refinement, Progress in Materials Science, 51(7), 881-981. Doi: 10.1016/j.pmatsci.2006.02.003.

Van Horn, K. R. 1968. Aluminum, American Society for Metals.

Venkatachalam, P., Kumar, S. R., Ravisankar, B., Paul, V. T., and Vijayalakshmi, M. 2010. Effect of processing routes on microstructure and mechanical properties of $2014 \mathrm{Al}$ alloy processed by equal channel angular pressing, Transactions of Nonferrous Metals Society of China, 20(10), 1822-1828. Doi:

Wang, C. T., Gao, N., Wood, R. J. K., and Langdon, T. G. 2011. Wear behavior of an aluminum alloy processed by equal-channel angular pressing, Journal of Materials Science, 46(1), 123-130. Doi: 10.1007/s10853-010-4862-0.

Williams, J. C., and Starke, E. A. 2003. Progress in structural materials for aerospace systems, Acta Material, 515775-5799. Doi: 10.1016/j.actamat.2003.08.023.

Wongsa-Ngam, J., Kawasaki, M., and Langdon, T. G. 2013. A comparison of microstructures and mechanical properties in a Cu$\mathrm{Zr}$ alloy processed using different SPD techniques, Journal of Materials Science, 48(13), 4653-4660. Doi: 10.1007/s10853-012-7072-0.

Xu, C., Dixon, W., Furukawa, M., Horita, Z., and Langdon, T. G. 2003. Developing superplasticity in a spray-cast aluminum 7034 alloy through equal-channel angular pressing, Materials Letters, 57(22-23), 3588-3592. Doi: 10.1016/S0167577X(03)00130-7.

$\mathrm{Xu}, \mathrm{C}$., and Langdon, T. G. 2007. The development of hardness homogeneity in aluminum and an aluminum alloy processed by ECAP, Journal of Materials Science, 42(5), 1542-1550. Doi: 10.1007/s10853-006-0899-5.

Zhang, Y., Wang, J. T., Cheng, C., and Liu, J. Q. 2008. Stored energy and recrystallization temperature in high purity copper after equal channel angular pressing, Journal of Materials Science, 43(23-24), 7326-7330. Doi: 10.1007/s10853-008-29038.

Zhao, Y. H., Liao, X. Z., Jin, Z., Valiev, R. Z., and Zhu, Y. T. 2004. Microstructures and mechanical properties of ultrafine grained $7075 \mathrm{Al}$ alloy processed by ECAP and their evolutions during annealing, Acta Materialia, 52(15), 4589-4599. Doi: 10.1016/j.actamat.2004.06.017.

Zheng, L. J., Chen, C. Q., Zhou, T. T., Liu, P. Y., and Zeng, M. G. 2002. Structure and properties of ultrafine-grained Al-Zn-Mg-Cu and $\mathrm{Al}-\mathrm{Cu}-\mathrm{Mg}-\mathrm{Mn}$ alloys fabricated by ECA pressing combined with thermal treatment, Materials Characterization, 49(5), 455-461. Doi: 10.1016/S1044-5803(03)00069-X.

Zhilyaev, A. P., Gubicza, J., Nurislamova, G., Revesz, A., Surinach, S., Baro, M. D., and Ungar, T. 2003. Microstructural characterization of ultrafine-grained nickel, Physica Status Solidi a-Applications and Materials Science, 198(2), 263271. Doi: $10.1002 /$ pssa.200306608.

Zhilyaev, A. P., Swaminathan, S., Gimazov, A. A., McNelley, T. R., and Langdon, T. G. 2008. An evaluation of microstructure and microhardness in copper subjected to ultra-high strains, Journal of Materials Science, 43(23-24), 7451-7456. Doi: 10.1007/s10853-008-2714-y. 